\title{
Profile of sexual function using Female Sexual Function Index (FSFI) in post- menopausal women in Geriatric Clinic, Dr Soetomo Hospital, Surabaya
}

\author{
Miftha Hurrahmi', Eighty Mardiyan K², Azami Denas A $^{2}$, Sulistiawati ${ }^{3}$ \\ 'Medical Doctor Program, ${ }^{2}$ Department of Obstetrics and Gynecology, ${ }^{3}$ Department of Public Health \\ and Preventive Medicine, Faculty of Medicine, Universitas Airlangga
}

\begin{abstract}
ABSTRAK
Tujuan: mengetahui gambaran fungsi seksual pada wanita pasca menopause di poli Geriatri RSUD Dr. Soetomo Surabaya pada bulan Mei 2016 serta menjelaskan faktor disfungsi seksual berdasarkan 6 domain seksual.

Bahan dan Metode: penelitian ini adalah penelitian deskriptif dengan metode survey untuk mendapatkan data variabel yang diteliti. Populasi penelitian ini adalah wanita pasca menopause di Poli Geriatri RSUD Dr. Soetomo Surabaya pada bulan Mei 2016. Kuesioner Female Sexual Function Index digunakan untuk mengumpulkan data. Jumlah populasi pada penelitian ini sebanyak 160 orang. Sampel yang memenuhi kriteria inklusi sebanyak 90 orang dan hanya 37 orang yang bersedia mengikuti penelitian ini.

Hasil: prevalensi sampel yang masih aktif melakukan hubungan seksual sebesar 29,7\%. Berdasarkan domain seksual prevalensi gangguan hasrat didapatkan sebesar $48,6 \%$, gangguan rangsangan sebesar $75,7 \%$, gangguan lubrikasi sebesar $73 \%$, gangguan orgasme sebesar $73 \%$, gangguan kepuasan sebesar 70,3\% dan gangguan nyeri sebesar $70,3 \%$. Penilaian fungsi seksual mendapatkan $78.4 \%$ mengalami disfungsi.

Simpulan: Prevalensi tinggi (78.4\%) disfungsi seksual pada wanita pasca menopause dipengaruhi oleh gangguan pada domain seksual. (MOG 2017;25:54-58)
\end{abstract}

Kata kunci: menopause; fungsi seksual; Female Sexual Function Index (FSFI)

\begin{abstract}
Objectives: to describe the profile of sexual function in postmenopausal women at Geriatric Clinic, Dr. Soetomo Hospital, Surabaya in May 2016 and to determine the factors of sexual dysfunction in 6 sexual domains.

Materials and Methods: a descriptive study using survey to obtain data on the examined variables. Population in this study was all post-menopausal women at Geriatric Clinic of Dr. Soetomo Hospital, Surabaya, in May 2016. Data were obtained using Female Sexual Function Index (FSFI) questionnaire.

Results: Total population in this study was 160 patients. The number of samples who met inclusion criteria were 90 patients, but only 37 were willing to participate. The prevalence of samples who were still active in sexual intercourse was $29.7 \%$. Based on 6 sexual domains, the prevalence of the lack of desire was $48.6 \%$, lack of arousal was $75.7 \%$, lack of lubrication was $73 \%$, lack of orgasm was $73 \%$, lack of satisfaction was $73 \%$ and pain was $70.3 \%$. The assessment of sexual function found that $78.4 \%$ of the samples were sexually dysfunctional.

Conclusion: The high prevalence (78.4\%) of sexual dysfunction in post-menopausal woman was caused by dysfunction in sexual domain. (MOG 2017;25:54-58)
\end{abstract}

Keywords: menopause; sexual function; Female Sexual Function Index (FSFI)

Correspondence: Miftha Hurrahmi, Medical Doctor Program, Faculty of Medicine, Universitas Airlangga. Jalan Mayjen Prof. Dr. Moestopo 47, Surabaya 60131, Indonesia. Phone: 082231651060. Email: hurrahmi.miftha@gmail.com

\section{INTRODUCTION}

An important factor of a marital relationship can be seen from sexual function. Sexual function can indirectly affect the quality of life of married couples. Sexual needs are a necessity of every human being, even in old age. ${ }^{1}$ However, in performing sexual function there are also obstacles or stressors. Stressor is an event or events that affect a person or an object that may finally end up in a stress reaction. ${ }^{2}$ One of the effects of stress is sexual dysfunction. Sexual dysfunction is a process that occurs in an individual due to the absence or inability to hold a sexual response to a cycle of sexual stimuli. ${ }^{3}$ Previous studies have found the prevalence of sexual dysfunction by $38 \%$ in 833 postmenopausal women aged 45-60 years. ${ }^{1}$ In addition, a 1991 study in 2000 in women with age range of 45-55 year revealed a sexual dysfunction prevalence of $30 \%$ in women that was closely associated with menopause. ${ }^{4}$
One method to determine the profile of sexual function in postmenopausal women is by using Female Sexual Function Index (FSFI). FSFI is a questionnaire containing 19 questions covering 6 sexual domains, the sexual arousal, sexual desire, orgasm, lubrication, satisfaction and pain during sexual activity. This instrument is used because it has a validity based on a clinical diagnosis on a sample of women who experience sexual function impairment. $^{5}$ This study aims to determine the description of sexual function using Female Sexual Function Index (FSFI) in post-menopausal women in Geriatric Clinic, Dr. Soetomo Hospital, Surabaya. Benefits that can be taken from this study is to provide understanding and description of sexual function in post-menopausal women in Geriatric Clinic, Dr. Soetomo Hospital, Surabaya. 


\section{MATERIALS AND METHODS}

This study was a descriptive survey to obtain data on the studied variables. The study was conducted in May 2016 at Geriatric Clinic, Dr. Soetomo Hospital, Surabaya. The population in this study were all postmenopausal women with age $\geq 55$ years old. The sample in this study was all postmenopausal women aged $\geq 55$ years old at Geriatric Clinic, Dr. Soetomo Hospital, Surabaya, that met the inclusion criteria. The inclusion criteria were women, married, still have a husband, in post-menopausal period, aged $\geq 55$ years old, and willing to be the respondent in this study, while the exclusion criteria were all patients at Geriatric Clinic, Dr. Soetomo Hospital, Surabaya, in May 2016 that did not meet the inclusion criteria. The sample size was determined by total sampling and the Solvin method formula to obtain a minimum of total samples. The type of data used was the primary data from Female Sexual Function Index (FSFI) questionnaire in postmenopausal women who met the inclusion criteria at Geriatric Clinic, Dr. Soetomo Hospital, Surabaya, in May 2016.

\section{RESULTS AND DISCUSSION}

The study was conducted from May to October 2016. Total female patients in Geriatric Clinic in May 2016 was 160 patients. Of these, patients who met the inclusion criteria were 90 patients. However, only 37 were willing to become the sample of this study, while according to Solvin method, the target samples were 114 patients.

Table 1. Characteristics of studied samples

\begin{tabular}{lcc}
\hline Characteristics & No of patients & $\%$ \\
\hline Patients' age (years) & 16 & $43.2 \%$ \\
$55-64$ & 16 & $51.4 \%$ \\
$65-74$ & 2 & $5.4 \%$ \\
$\geq 75$ & & \\
Patients' husband age & 9 & $24.3 \%$ \\
$\quad 55-64$ & 19 & $51.4 \%$ \\
$65-74$ & 9 & $24.3 \%$ \\
$\quad \geq 75$ & 13 & $35.1 \%$ \\
Occupation & 7 & $18.9 \%$ \\
$\quad$ Housewive & 17 & $45.9 \%$ \\
$\quad$ Working & & \\
$\quad$ Retired & & \\
Length of marriage & & \\
(years) & & $18.9 \%$ \\
$\quad 35$ & 17 & $45.9 \%$ \\
$36-45$ & 13 & $35.1 \%$ \\
$\geq 46$ & 13
\end{tabular}

\begin{tabular}{lcc} 
Children & & \\
Have & 0 & $0 \%$ \\
$\quad$ Do not have & 37 & $100 \%$ \\
$\begin{array}{l}\text { Menopausal period } \\
\text { (years) }\end{array}$ & & \\
$\leq 10$ & 9 & $24.3 \%$ \\
$11-20$ & 16 & $43.2 \%$ \\
$\geq 21$ & 12 & $32.4 \%$ \\
\hline
\end{tabular}

Characteristics of the studied sample based on age of the patient and the age of their husbands showed tha most of the patients were in age range of 65-74 years (51.4\%), most of them retired (45.9\%), especially those from Dr. Soetomo Hospital, Surabaya. The longest age of marriage was $36-45$ years $(45.9 \%)$ and the longest menopause was $11-20$ years $(43.2 \%)$. All samples $(100 \%)$ in this study had children.

Table 2. Distribution of sample based on sexual activity

\begin{tabular}{lcc}
\hline \multicolumn{1}{c}{ Results } & $\begin{array}{c}\text { Number } \\
\text { (patients) }\end{array}$ & $\%$ \\
\hline $\begin{array}{l}\text { No sexual intercourse } \\
\text { Have sexual } \\
\text { intercourse }\end{array}$ & 26 & $70.3 \%$ \\
\hline Total & 11 & $29.7 \%$ \\
\hline
\end{tabular}

In this study 26 people (70.3\%) had not had sexual intercourse during the last 4 weeks and only 11 patients (29.7\%) were still having sexual intercourse. The low rate in this study was influenced by several factors. One was the elderly age. Elderly age is identical with the climacterium, which is the transition between reproductive period and senium period in women aged 40-65 years. ${ }^{6}$ The phase is divided into three stages, the period before, during and after menstruation. ${ }^{7}$ The average age of Indonesian female menopause is $50-52$ years and perimeopause at age $40-50$ years. $^{6}$ In this study, the subject age range was 55-82 years, which is the age range in the climacterium period. A study in 1994 showed that postmenopausal women had some variations in their cycle. There were some who still experienced menstruation despite high FSH levels, and there were also women with high FSH levels and low estrogen levels. Some had fluctuating levels of FSH and estrogen. ${ }^{8}$ At menopausal stage, follicular development becomes fewer, resulting in a change from the rich follicles that producing estrogen and progesterone to the fewer follicles that producing estrogen and androgens. In addition, irregular menstruation causes the endome- 
trium to lose stimulation of the hormone estrogen. Furthermore, the menstrual period will stop. ${ }^{7}$

Table 3. Results of the study using Female Sexual Function Index (FSFI) based on the six domains

\begin{tabular}{lcccc}
\hline \multirow{2}{*}{ Domains } & \multicolumn{2}{c}{ Normal } & \multicolumn{2}{c}{ Dysfunction } \\
\cline { 2 - 5 } & $\sum$ & $\%$ & $\sum$ & $\%$ \\
\hline Desire & 19 & $51.4 \%$ & 18 & $48.6 \%$ \\
Arousal & 9 & $24.3 \%$ & 28 & $75.7 \%$ \\
Lubrication & 10 & $27 \%$ & 27 & $73 \%$ \\
Orgasm & 10 & $27 \%$ & 27 & $73 \%$ \\
Satisfaction & 11 & $29.7 \%$ & 26 & $70.3 \%$ \\
Pain & 11 & $29.7 \%$ & 26 & $70.3 \%$ \\
\hline
\end{tabular}

Six FSFI sexual domains have cutoffs in each of their domains. Desire has a domain value with a cutoff of 2.4. Values below 2.4 fall into the category of dysfunction, and above 2.4 fall into normal category. The other five domains, the stimulation, lubrication, orgasm, satisfaction and pain, have a cutoff value of 3.6. Values below 3.6 belong to dysfunction category, while above 3.6 is considered normal. ${ }^{9}$

In this study, dysfunction disorder in the domain of desire was found in 18 samples $(48.6 \%)$, while 19 samples (51.4\%) still had normal desires. In addition to filling out the questionnaires, the samples were also interviewed about sexual activity with their partners. Of the 37 samples, there were 4 patients who scored 4.2 to 6 for questions about the domain desires. These results were quite different from other samples whose average scores were 1.2 to 2.4. From the results of interviews with samples with high score, it was found that the samples did not have disorder in the domain of desire to the sexual partner. High scores on this question are consistent with previous studies ${ }^{10}$ that postmenopausal women aged 70 years to 80 years tend to be more interested in sex than men because they do not have to be afraid of the risks of getting pregnant. But for low scores, according to a previous study conducted in Japan with a sample of elderly women aged over 55 years, elderly women sometimes engage in sexual activity with their partners without any sexual desire in them and merely want to satisfy the desires of their respective spouses. ${ }^{11}$

Disturbance in the arousal domain was found in 28 patiens $(75.7 \%)$ and 9 patiens $(24.3 \%)$ had no disturbance in the arousal domain. Disturbance in this domain can be caused by several factors, including vascular insufficiency, atherosclerosis and fibrosis, endothelial dysfunction, disruption of endocrine hormones, diabetes and the use of antidepressants. ${ }^{12}$ The interview revealed that some samples had metabolic disease, such as hypertension, diabetes mellitus, cholesterol, gallstones, heart disease, and others. This is in accordance with previous research. However, of the 9 patients who did not have disturbance in stimulus domain, 2 samples had a score of 5 or a maximum score for questions about stimuli.

The prevalence of disorder in the domain lubrication was found in 27 patients $(73 \%)$ and the remaining 10 (27\%) did not experience any disturbance in this domain. The results of the questionnaire revealed that there were 4 patients not having lubrication disorder as they had a score of 5 on the question, but the rest had low scores on this question. This is because at the time of transition from menstruation to menopause, there is a decrease in estrogen levels in women, while androgen levels have begun to fall at age 25 years and peak at the time of menopause. This is referred to as vaginal atrophy where there is a decrease in estrogen levels and predisposes to lubrication problems. ${ }^{13}$ In addition, postmenopausal women with vaginal atrophy also experience a decrease in the frequency of sexual activity due to pain because of the dry vaginal area. ${ }^{14}$ Interviews with some low-scoring patients on questions about lubrication domains revealed information about the use of gel or lubricant prior to having sexual intercourse with their partner to moisten the vaginal area and prevent the occurrence of pain that will arise during sexual intercourse.

Impaired orgasm function was found in 27 patients $(73 \%)$ of total sample, while the rest, as many as 10 patients $(27 \%)$, did not experience the disorder. From the results of the questionnaires, 5 patients had high scores, ie 5.2 to 6 , on questions about the domain of orgasm. Additional information obtained at the time of the interview was that in women with high scores who had a marriage age of more than 30 years, the average distance between the samples' age and their spouses was between 1 and 3 years and was also sexually active in the last 4 weeks. This was very influential on sexual communication between one another. One association between the age of marriage and the function of a woman's orgasm is that the woman has knowledge on sexual activity so that they can feel comfortable, acceptable and able to express sexual sensation, ${ }^{9}$ while their partner can know how much stimulation should be given to the woman to feel comfortable during sexual activity.

Furthermore, the prevalence of disorder in the domain satisfaction in the sample were 26 people $(70.3 \%)$ and those who did not experience disorder were as many as 11 patients $(29.7 \%)$. This was inversely proportional to the results of the existing studies. The results of the questionnaire showed 1 patient with a maximum score (6) for questions about the domain of satisfaction. The interviews also showed that the samples were very 
satisfied in sexual activity during the last 4 weeks due to trust, good relationship, and communication with her sexual partner. This was supported by previous studies, ${ }^{15}$ that good communication between sexual partners, while not engaging in sexual activity, is associated with a high level of satisfaction. As to the last domain, the pain, the prevalence of pain was in 26 patients $(70.3 \%)$ and those who did not experience the disorder were 11 patients $(29.7 \%)$. The factor of elderly age is the key to this problem. At an advanced age, ovaries produce less estrogen which affects the production of vaginal secretions as a moisturizer for the vagina.

The decrease in secretion production causes vaginal discomfort during sexual intercourse which can sometimes also cause irritation and infection. ${ }^{10}$ Not only does the production decrease in secretions, but there is also a decrease of desire or libido and atrophy in the vaginal wall. Pain during sexual intercourse lowers the frequency of sexual intercourse so that the vaginal wall becomes atrophy and further aggravate the situation. ${ }^{16}$ In addition, according to some reports, postmenopausal women with vaginal atrophy are less likely to have sexual intercourse because of fear of pain that will be felt. ${ }^{14}$ From questionnaires and interviews it was found that 11 patients who did not experience pain disorders during sexual intercourse had scores above 3.6, which is the limit of scores for the domain pain. From these data it can be concluded that all patients who had sexual intercourse did not experience pain. The value of the disturbance in pain was high because the sample did not have sexual intercourse in the last 4 weeks.

Table 4. Profile of sexual function in post-menopausal women in Geriatric Clinic, Dr. Soetomo Hospital, Surabaya, in May 2016

\begin{tabular}{lcc}
\hline \multicolumn{1}{c}{ Outcome } & $\begin{array}{c}\text { Number of } \\
\text { patients }\end{array}$ & $\%$ \\
\hline $\begin{array}{l}\text { Sexual dysfunction } \\
\text { No Sexual } \\
\text { dysfunction }\end{array}$ & 29 & $78.4 \%$ \\
\hline Total & 8 & $21.6 \%$ \\
\hline
\end{tabular}

Profile of sexual function in post-menopausal women in Geriatric Clinic, Dr. Soetomo Hospital in May 2016 using the Female Sexual Function Index (FSFI) questionnaire showed the category of sexual dysfunction if the score $\leq 26.55$ for total aggregated score of each question on sexual domains. From the results of the assessment using the questionnaire, the prevalence of sexual dysfunction was found in 29 patients $(78.4 \%)$ and 8 patients $(21.6 \%)$ did not show sexual dysfunction of the total sample of 37 patients.
Sexual dysfunction is defined as psychophysiological changes in sexual cycle and may cause discomfort and personal problems. ${ }^{17}$ The World Health Organization's International Statistical Classification of Disease and Related Health Problems (ICD-10) defines sexual dysfunction as a condition in which an individual cannot participate in desired sexual activity by each individual. $^{18}$

\section{CONCLUSION}

High prevalence (78.4\%) of sexual dysfunction in postmenopausal women is affected by disorders in sexual domains. Based on sexual domains, the preva-lence of desire disorder was $48.6 \%$, arousal disorder $75.7 \%$, lubrication disorder $73 \%$, orgasm disorder $73 \%$, satisfaction disorder $70.3 \%$ and pain $70.3 \%$. Further studies using larger samples and longer time are needed to accurately identify sexual function profile in postmenopausal women.

\section{REFERENCES}

1. Andini A. Hubungan lama menopause dengan kejadian disfungsi seksual pada wanita menopause di posyandu lansia wilayah kerja Puskesmas Panjang Bandar Lampung. Undergraduate Thesis. Lampung University; 2015.

2. Wibowo AF, Yuliadi I, Karyanta NA. Perbedaan derajad disfungsi ereksi pria dewasa awal ditinjau dari tingkat stres di kelurahan jagalan surakarta. Jurnal Ilmiah Psikologi Candrajiwa. 2013;2(4): 8392

3. Semiun Y. Kesehatan Mental 2. Yogyakarta: Penerbit Kanisius; 2006 p. 43.

4. Dennerstein L, Dudley E, Burger H. Are changes in sexual function during midlife due to aging or menopause? American Society of Reproductive Medicine. 2001. 76(3);456-60.

5. Rosen R, Brown C, J. Heiman, et al. The Female Sexual Function Index (FSFI): A Multidimensional Self-Report Instrument for the Assesment of Female Sexual Function. Journal of Sex and Marital Theraphy. 2000. 26;191-208.

6. Mawaddah M. Determinan kecemasan wanita pra menopause di Desa Rawang Lama Kecamatan Rawang Panca Arga, Kabupaten Asahan Tahun. Thesis. Sumatera Utara University; 2014.

7. Tambunan, EDY. Gambaran pengetahuan dan sikap wanita usia 40-50 tahun tentang menopause di wilayah kerja Puskesmas Sigumpar, Kabupaten Toba Samosir Tahun 2010.Undergraduate Thesis. Sumatera Utara University; 2010. 
8. Love SM. Hormone Book. USA: Random House, Inc. 1997; p. 13.

9. Jiann BP, Su CC, Yu CC, et al. Risk factors for individual domains of female sexual function. J Sex Med. 2009:3364-75.

10. Cherry SH and Runowicz CD. The Menopause Book: A guide to health and well-being for women after forty. USA: Macmillan Publishing Company; 1994. p. 35.

11. Takahashi $\mathrm{M}$, Inokuchi $\mathrm{T}$, Watanabe $\mathrm{C}$ et al. The Female Sexual Function Index (FSFI): Development of a Japanese version. The Journal of Sexual Medicine. 2011;8(8):2246-54.

12. Kim NN and Traish AM. Pathophysiologic mechanism involved in genital arousal dysfunction. In: Women's sexual function and dysfunction: Study, diagnosis and treatment. 2005.

13. Gregersen N, Jensen PT, Giraldi AGE. Sexual dysfunction in the peri- and postmenopause. Danish Medical Bulletin. 2006;53(3):349-53.
14. Chedraui P, Perez-Lopez FR, San Miguel G, Avila C. Assessment of sexuality among middle-aged women using the Female Sexual Function Index. Climacteric. 2009, 12;213-221

15. Thomas HN, Hess R, Thurston RC. Correlates of sexual activity and satisfaction in midlife and older women. Annals of Family Medicine. 2015; 13 (04);336-42

16. Kamezaki A and Saito H. Study on the sexuallity of menopausal women and related factor. Kawasaki Journal of Medical Welfare. 2006;11(2);77-83.

17. Royo FC, Redondo Cc, Toves LAR, et al. Female sexual function in Castilla Y Leon (Spain): Normal ranges. Journal Gynecology \& Obstetrics. 2004; 4(9):1-6

18. Patel M, Brown CS, Bachmann G. Sexual function in the menopause and perimenopause. In: Goldstein I, Meston CM, Davis S, Traish A, editors. Women's sexual function and dysfunction: Study, diagnosis and treatment. CRC Press; 2005. 